\title{
Radiographic evaluation of cervical spine of subjects with temporomandibular joint internal disorder
}

\section{Avaliação radiográfica da coluna cervical de indivíduos com distúrbios internos da articulação temporomandibular}

\author{
Wagner Cesar Munhoz* \\ Amélia Pasqual Marques** \\ José Tadeu Tesseroli de Siqueira***
}

\begin{abstract}
Although the etiopathophysiology of internal temporomandibular joint internal disorders (TMJ ID) is still unknown, it has been suggested that head and body posture could be related to its initial onset, development and perpetuation. The purpose of the present study was to observe the relationship between cervical spine X-ray abnormalities and TMJ ID. This investigation evaluated 30 subjects with internal TMJ disorder symptoms (test group) and 20 healthy subjects (control group). Subjects were submitted to clinical and radiographic evaluation. Clinical evaluation comprised anamnesis and stomatognathic system physical examination. Radiographic evaluation comprised analysis of lateral cervical spine X-rays by three physical therapists and tracing on the same images. The test group presented twice as much cervical spine hyperlordosis as the control group $(20.7 \%$ versus $10.5 \%)$, but almost half of rectification prevalence ( 41.4 versus $79.0 \%, p=0.03)$. After that, the test group was divided into three subgroups according to TMJ dysfunction severity, evaluated by Helkimo's index. These subgroups were not significantly different, but the subgroup with more severe TMD showed a tendency to cervical spine hyperlordosis prevalence. Results showed a tendency for subjects with more severe TMD to exhibit cervical spine hyperlordosis. Nevertheless, studies with a larger number of subjects suffering from severe TMD are encouraged in order to corroborate the present findings.
\end{abstract}

DESCRIPTORS: Temporomandibular joint disorders; Spinal column; Radiography; Posture.

RESUMO: Apesar de a etiofisiopatologia dos distúrbios internos (DI) da articulação temporomandibular (ATM) ser ainda desconhecida, sugere-se que as posturas de cabeça e corpo estariam associadas a seu desencadeamento, desenvolvimento e sua perpetuação. O objetivo deste estudo foi verificar a relação entre alterações radiográficas de coluna cervical e distúrbios internos da ATM. Este estudo avaliou 30 indivíduos com distúrbios da ATM (grupo teste) e 20 saudáveis (grupo controle). Os indivíduos submeteram-se à avaliação clínica e radiográfica. A avaliação clínica consistiu de anamnese e exame físico do sistema estomatognático. A avaliação radiográfica consistiu de análise de radiografias laterais de coluna cervical por fisioterapeutas e traçados. O grupo teste apresentou o dobro da prevalência de hiperlordose de coluna cervical $(20,7 \%$ versus $10,5 \%)$ e quase a metade $(41,4 \%$ versus $79,0 \%)$ de retificação $(p=0,03)$. Em um segundo momento, o grupo teste foi subdividido em três subgrupos em função da gravidade clínica da disfunção temporomandibular, avaliada pelo índice de Helkimo. Não houve diferença estatisticamente significante entre os subgrupos, mas se constatou uma tendência do subgrupo com disfunção grave a apresentar prevalência de hiperlordose cervical. Esses resultados sugerem uma tendência dos indivíduos com disfunção temporomandibular (DTM) grave a apresentarem hiperlordose. No entanto, futuros estudos devem ser feitos, analisando-se um maior número de indivíduos portadores de DTM grave para corroborar nossos achados. DESCRITORES: Transtornos da articulação temporomandibular; Coluna vertebral; Radiografia; Postura.

\section{INTRODUCTION}

Temporomandibular joint internal disorders (TMJ ID) are a specific category of TMJ dysfunction (TMD), a condition in which tissue morphology and healthy biodynamic joint elements are jeopardized, and which may lead to TMJ noises, altered mandibular movements, and pain ${ }^{9}$. Musculoskeletal pain and altered mandibular movements may compromise the TMJ system and adjacent craniocervical region ${ }^{2}$.

\footnotetext{
*M.S.; **Professor of Physical Therapy, Department of Physical Therapy, Phonoaudiology and Occupational Therapy; ***Coordinator of the Orofacial Pain and Temporomandibular Joint Team, Clinical Hospital - School of Medicine, University of São Paulo.
} 
Munhoz WC, Marques AP, Siqueira JTT. Radiographic evaluation of cervical spine of subjects with temporomandibular joint internal disorder. Braz Oral Res 2004;18(4):283-9.

The etiopathophysiology of TMD is still unclear. Some authors believe that head ${ }^{6}$ or body posture ${ }^{8}$ plays a role in TMD onset and development. The reasoning would be that a chronically altered craniocervical posture could lead to mandibular postural changes through biomechanical ${ }^{4}$ and neuromuscular mechanisms ${ }^{3}$. Some authors have reported postural pattern alterations in TMD subjects in comparison with healthy subjects ${ }^{6,7,10}$, while others ${ }^{1}$ have not found any differences between TMD and healthy subjects.

\section{OBJECTIVES}

- To compare cervical spine radiographs of TMJ ID subjects with those of healthy subjects.

- To verify the existence of a correlation between TMJ ID severity and cervical spine lateral profile changes viewed on X-rays.

\section{MATERIAL AND METHODS Subjects}

Fifty subjects were selected, with ages ranging from 16 to 35 years, and divided into test group ( $\mathrm{n}=30$; mean age of $22.90 \pm 5.31$ ), and control group ( $n=20$; mean age of $21.70 \pm 3.64)$.

The test group was randomly selected among patients undergoing treatment at the Orofacial Pain Clinic, Dentistry Center, Medical School Hospital, University of São Paulo, and university students. Subjects' selection criteria followed the classification of TMJ ID symptoms of the American Academy of Orofacial Pain ${ }^{9}$ : internal noises detectable by TMJ lateral and/or posterior poles palpation associated with disharmonic mandibular movements (opening, closing, lateral excursions and/ or protrusion), or yet limitations of these movements with specific clinical characteristics. Painful symptoms in masticatory muscles or TMJ, whether spontaneous or elicited by manual palpation, were not a reason for exclusion from the test group.

The control group was comprised of university students that did not show signs or symptoms of TMD during anamnesis and clinical examination.

In the control group, subjects exhibiting the following conditions were excluded from the study: masticatory muscle pain, whether spontaneous or upon manual palpation without TMJ noises; otological origin noise complaints not related to TMJ; undetected TMD previous history during the clinical examination; macro-trauma history in the head or spine areas; and absence of unilateral or bilateral posterior teeth.

None of the participating subjects had been previously subjected to posture correcting treatment. All of them signed a written informed consent form before enrollment in this study, which was approved by the School of Medicine Ethics Committee Institutional Review Board.

Subjects' evaluation consisted of two parts:

1. stomatognathic system evaluation, or more specifically, evaluation of the temporomandibular system (TMJ, masticatory muscles and ligaments) and occlusal condition;

2. subject's lateral cervical X-ray evaluation in orthostatic postural position.

\section{Stomatognathic system evaluation}

The used protocol included detailed anamnesis of the patient's complaint history ${ }^{11}$ and Helkimo's anamnestic and dysfunctional indexes ${ }^{5}$.

From the data obtained, the subjects' profile was established, according to craniofacial pain intensity and frequency, dental and occlusion conditions, as well as health status or functional disease of the temporomandibular system.

\section{Radiographic evaluation}

Imaging of cervical spine in lateral projection was carried out according to standardized procedure of the Radiology Institute, Clinical Hospital, University of São Paulo. For each subject, 240 x 300 X-ray film (Kodak Lanex Regular 5, Kodak, New York, USA), mounted on a cassette (Kodak X-OMATIC cassette, Kodak, New York, USA) containing double screen (Rare Earths), focus-film distance of $1.50 \mathrm{~m}, 1 \mathrm{~s}$ exposure, 74$78 \mathrm{kV}$ and $12 \mathrm{~mA}$ (Solarix model X-ray equipment, G.E., Toronto, Canada) was used. The X-rays were electronically identified (Kodak X-OMATIC Identification Camera, Kodak, New York, USA). Development and drying were done using electronic processing equipment (Kodak X-OMATIC M20-Br, Kodak, New York, USA). The X-ray was taken with the patient's mid-sagittal plane parallel to the X-ray film plane, barefoot, with feet together, in an orthostatic posture and instructed to look toward the horizon ${ }^{13}$. These technical adaptations were made in order to provide similarity between the X-ray image and the patient's head and neck profile when observed in the standard orthostatic posture position. 
Munhoz WC, Marques AP, Siqueira JTT. Radiographic evaluation of cervical spine of subjects with temporomandibular joint internal disorder. Braz Oral Res 2004;18(4):283-9.

X-rays were digitalized (Scanner Genius ${ }^{\circledR}$ HR5 PRO, KYE System Corporation, Hong Kong, China) according to a scanning standard adapted to graytone radiographic imaging. Cervical spine profile radiograph tracings were adapted from those described by Huggare, Raustia ${ }^{6}$ (1992):

1. posterior nasal spine to lower surface point of the occipital bone line;

2. line tangent to the odontoid apophysis posterior surface;

3. line tangent to $\mathrm{C} 3-\mathrm{C} 4$ cervical vertebrae bodies (from two reference points: the highest point on the C3 posterior surface and the lowest point on the $\mathrm{C} 4$ posterior surface).

Two angles are formed by intersecting these three lines: cranium base/odontoid apophysis angle, which measures the head's degree of extension over the high cervical spine; and odontoid apophysis/C3-C4 lines, which indicates the ratio between the high and low cervical spine (Figure 1).

$\mathrm{X}$-rays were also evaluated by three physical therapists in order to identify the cervical spine curvature pattern, which was classified as: rectification, physiologic lordosis or hyperlordosis.

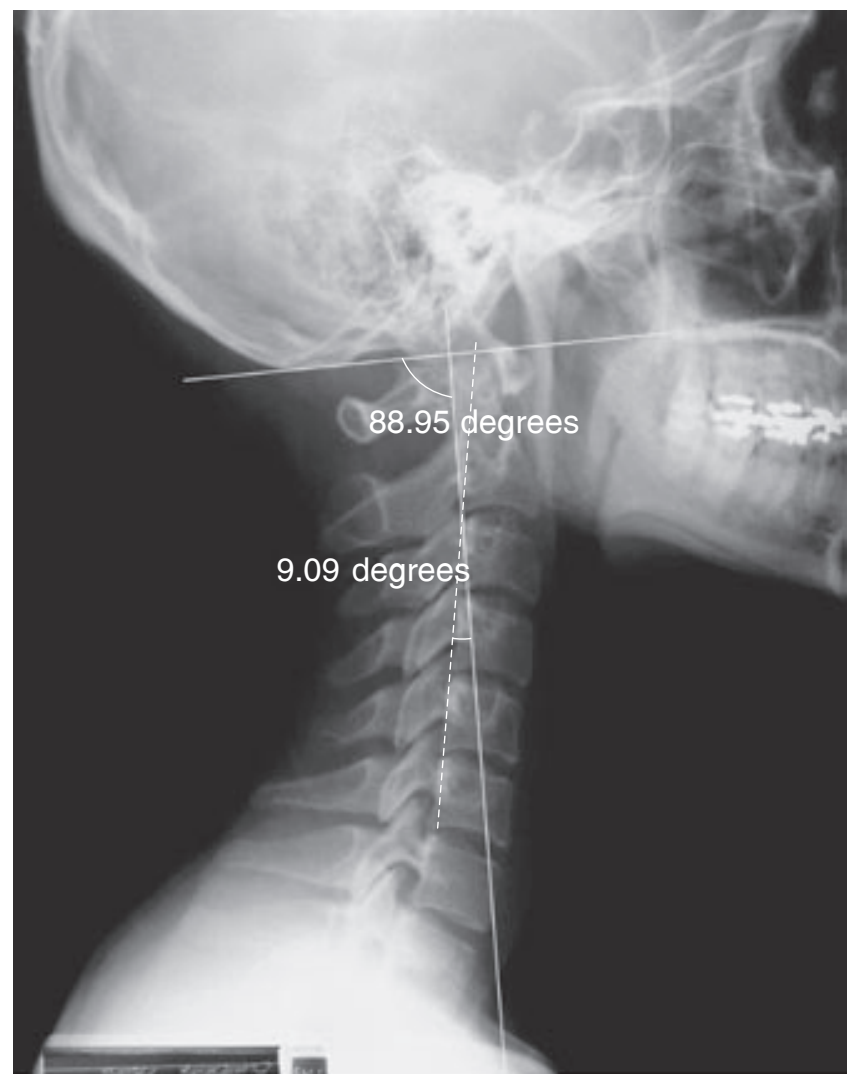

FIGURE 1 - An illustrative diagram of the method used for craniocervical radiographic tracings.
They did not have any knowledge of this study's objectives, nor of the subject's group. The presence or absence of curvature was defined by diagnosis agreement of at least two of the three evaluators.

In order to determine if TMJ ID subjects also had a more altered cervical spine X-ray profile than healthy subjects, all statistical analyses were carried out through comparisons between test and control groups. However, to investigate positive correlations between TMD severity and cervical spine X-ray patterns, comparisons were made using subgroups derived from the test group.

Subgroups were numbered one to three, according to TMD severity, as reported by Helkimo's dysfunctional index.

\section{Statistical analysis}

All variables were initially tested in order to determine variance homogeneity using Levene's test and data normalcy using Kolmogorov-Smirnov's test. Since these tests showed variance homogeneity and data normalcy, only parametric tests were applied.

Groups were compared using Student's $t$-test and the three subgroups were compared using ANOVA. Qualitative variables were evaluated by the chi-square test and when it did not apply, by Fisher's exact test.

Agreement interpretation rate among the three $\mathrm{X}$-ray evaluators was estimated by statistical methods proposed by Viikari-Juntura ${ }^{12}$ (1987).

\section{RESULTS \\ Subjects' biodemographic characteristics}

Table 1 shows subjects' biodemographic characteristics. There were no statistical significant differences between the two groups regarding gender, ethnical group and age variables. Therefore, they were considered as homogeneous.

\section{Stomatognathic system evaluation}

Results found for Helkimo's Anamnestic and Clinical Dysfunction Indexes are seen in Table 2. The Anamnestic index (Ai), which assessed participants' self-reported dysfunctional complaints, was zero in all control group subjects, whereas in the test group, 3 subjects (10\%) did not report any sign of dysfunction $(\mathrm{Ai}=0) ; 8(26.7 \%)$ reported dysfunctional symptomatology considered mild $(\mathrm{Ai}=\mathrm{I})$ and 19 (63.3\%) reported severe dysfunctional symptomatology $(\mathrm{Ai}=\mathrm{II})$. One hundred percent of the 
Munhoz WC, Marques AP, Siqueira JTT. Radiographic evaluation of cervical spine of subjects with temporomandibular joint internal disorder. Braz Oral Res 2004;18(4):283-9.

TABLE 1 - Biodemographic features of test and control group subjects.

\begin{tabular}{|c|c|c|c|c|}
\hline \multicolumn{2}{|r|}{ Variable } & $\begin{array}{l}\text { Control group } \\
(\mathrm{n}=20)\end{array}$ & $\begin{array}{l}\text { Test group } \\
(\mathrm{n}=30)\end{array}$ & Test \\
\hline \multirow{2}{*}{ Gender } & Male & 6 & 3 & \multirow{2}{*}{$\begin{array}{c}\text { Fisher } \\
\mathrm{p}=0.13(\mathrm{~ns})\end{array}$} \\
\hline & Female & 14 & 27 & \\
\hline \multirow{3}{*}{ Age } & Mean $\pm \mathrm{SD}$ & $21.7 \pm 3.6$ & $22.9 \pm 5.3$ & \multirow{3}{*}{$\mathrm{p}=0.38$-test } \\
\hline & Median & 21 & 21 & \\
\hline & Minimum - Maximum & $18-32$ & $16-35$ & \\
\hline \multirow{3}{*}{$\begin{array}{l}\text { Ethnic } \\
\text { group }\end{array}$} & White & 14 & 25 & \multirow{3}{*}{$\begin{array}{c}\text { Chi-square } \\
\mathrm{p}=0.36 \text { (ns) }\end{array}$} \\
\hline & Asian & 5 & 3 & \\
\hline & Black & 1 & 2 & \\
\hline
\end{tabular}

$\mathrm{ns}=$ no statistical significance; SD: standard deviation.

control group subjects exhibited a dysfunction index (Di) of zero, whereas in the test group 15 individuals $(50 \%)$ showed signs and symptoms of mild TMJ dysfunction (Di = I), $9(30 \%)$ of moderate $(\mathrm{Di}=\mathrm{II})$ and $6(20 \%)$ of severe $(\mathrm{Di}=\mathrm{III})$. The two groups differed regarding reported $(p=0.0000)$ and clinical presence of TMD $(p=0.0000)$.

\section{Cervical spine X-rays}

Results of quantitative and qualitative analyses of head and cervical spine postures are shown in Table 3. There were no statistically significant variations in head forward extension degree between both groups: $89.30 \pm 7.74^{\circ}$ cranium basisodontoid apophysis angle for the test group and $91.10 \pm 6.78^{\circ}$ for the control group $(p=0.41)$.

The angle formed by $\mathrm{C} 3 / \mathrm{C} 4$ and odontoid apophysis lines measures the longitudinal ratio between the high and low cervical spine. Results for this angle were similar between the two groups:

TABLE 2 - Helkimo's indexes applied to test and control groups.

\begin{tabular}{|c|c|c|c|c|}
\hline \multicolumn{2}{|c|}{ Variable } & $\begin{array}{l}\text { Control } \\
(\mathrm{n}=20)\end{array}$ & $\begin{array}{c}\text { Test } \\
(\mathrm{n}=30)\end{array}$ & Chi-square \\
\hline \multirow{3}{*}{$\mathrm{Ai}$} & 0 & $20(100.0 \%)$ & 3 (10.0\%) & \multirow{3}{*}{$p=0.000^{*}$} \\
\hline & I & - & $8(26.7 \%)$ & \\
\hline & II & - & 19 (63.3\%) & \\
\hline \multirow{4}{*}{ Di } & 0 & 20 (100.0\%) & - & \multirow{4}{*}{$\mathrm{p}=0.000^{*}$} \\
\hline & I & - & $15(50.0 \%)$ & \\
\hline & II & - & 9 (30.0\%) & \\
\hline & III & - & 6 (20.0\%) & \\
\hline
\end{tabular}

*Statistically significant value. Ai: anamnestic index. Di: dysfunction index.
$10.68 \pm 4.85^{\circ}$ for the test group and $10.33 \pm 4.12^{\circ}$ for the control group $(\mathrm{p}=0.79)$.

Chi-square test $(\mathrm{p}=0.03)$ applied by the three physical therapists to subjects' X-rays showed significant statistical differences between the two groups.

In the test group, $20.7 \%$ of the subjects showed hyperlordotic curve, $37.9 \%$ showed physiologic lordosis, and $41.4 \%$ showed rectification. Results for the control group were: hyperlordosis $-10.5 \%$, physiologic lordosis $-10.5 \%$ and rectification $-79 \%$. Regarding subjects' X-rays, $83.6 \%$ of diagnostic agreement was observed among the three evaluators (Table 3).

\section{Subgroups}

Based on Helkimo's dysfunctional index, the test group was subdivided into three subgroups, numbered I to III, according to the degree of TMD severity. Statistical tests showed homogeneity among the subgroups regarding age, ethnicity, gender, and duration of complaint (Table 4). Higher dysfunction severity resulted from worsening of TMJ ID and masticatory muscles dysfunction. Since dysfunctional index is non-specific for muscle and/or joint dysfunctions, in subgroups with higher dysfunctional indexes, a progressive increase in muscle palpation tenderness was found (Table 5).

Table 6 shows no significant statistical variations among subgroups, either for head extension or high and low cervical spine profile. However, the X-ray evaluations made by the three physical therapists showed a tendency, although not statistically significant, toward more pronounced hyperlordosis in subgroups with higher degree of dysfunction. As seen in Table 6, hyperlordo- 
Munhoz WC, Marques AP, Siqueira JTT. Radiographic evaluation of cervical spine of subjects with temporomandibular joint internal disorder. Braz Oral Res 2004;18(4):283-9.

TABLE 3 - Radiographic analysis diagram interpretation and clinical diagnoses of lateral cervical spine X-rays according to the three different examiners.

\begin{tabular}{|c|c|c|c|c|}
\hline \multicolumn{2}{|c|}{ Variable } & $\begin{array}{l}\text { Control } \\
\mathrm{n}=19\end{array}$ & $\begin{array}{c}\text { Test } \\
\mathrm{n}=29\end{array}$ & Statistical test \\
\hline \multirow{3}{*}{$\begin{array}{l}\text { Cranium basis-odontoid } \\
\text { angle }\end{array}$} & Mean \pm SD & $91.10 \pm 6.78^{\circ}$ & $89.30 \pm 7.74^{\circ}$ & \multirow{3}{*}{$\mathrm{p}=0.413(\mathrm{~ns})$} \\
\hline & Median value & $90.82^{\circ}$ & $88.78^{\circ}$ & \\
\hline & Range & $81.26^{\circ}-105.30^{\circ}$ & $75.51^{\circ}-101.92^{\circ}$ & \\
\hline \multirow{3}{*}{ Odontoid-C3/C4 angle } & Mean \pm SD & $10.33 \pm 4.12^{\circ}$ & $10.68 \pm 4.85^{\circ}$ & \multirow{3}{*}{$\begin{aligned} & t \text {-test } \\
\mathrm{p}= & 0.79(\mathrm{~ns})\end{aligned}$} \\
\hline & Median value & $9.78^{\circ}$ & $9.68^{\circ}$ & \\
\hline & Range & $1.65^{\circ}-17.26^{\circ}$ & $1.65^{\circ}-19.25^{\circ}$ & \\
\hline \multirow{3}{*}{ Clinical diagnoses } & Rectification & $15(79.0 \%)$ & $12(41.4 \%)$ & \multirow{3}{*}{$\begin{array}{c}\text { Agreement } \\
83.6 \% \\
\text { Significance } \\
\text { p }=0.03^{*}\end{array}$} \\
\hline & Physiologic lordosis & $2(10.5 \%)$ & $11(37.9 \%)$ & \\
\hline & Hyperlordosis & $2(10.5 \%)$ & $6(20.7 \%)$ & \\
\hline
\end{tabular}

SD: standard deviation. ns: no statistical significance. *Statistically significant value.

TABLE 4 - Biodemographic features and duration of complaints (months) of subgroup subjects.

\begin{tabular}{|c|c|c|c|c|c|}
\hline \multicolumn{2}{|c|}{ Variable } & $\begin{array}{l}\text { Subgroup I } \\
\text { Di = I } \\
(\mathrm{n}=15)\end{array}$ & $\begin{array}{c}\text { Subgroup II } \\
\mathrm{Di}=\mathrm{II} \\
(\mathrm{n}=9)^{*}\end{array}$ & $\begin{array}{c}\text { Subgroup III } \\
\text { Di = III } \\
(\mathrm{n}=6)\end{array}$ & Statistical test \\
\hline \multirow{3}{*}{ Age } & Mean \pm SD & $22.40 \pm 5.85$ & $22 \pm 3.64$ & $25.50 \pm 5.99$ & \multirow{3}{*}{$\begin{array}{c}\text { ANOVA } \\
\mathrm{p}=0.414(\mathrm{~ns})\end{array}$} \\
\hline & Median value & 20 & 20 & 24 & \\
\hline & Range & $16-34$ & $17-27$ & $19-35$ & \\
\hline \multirow{3}{*}{ Ethnic group } & White & $11(73.33 \%)$ & 8 (88.90\%) & $6(100 \%)$ & \multirow{3}{*}{$\begin{array}{c}\text { Chi-square } \\
\mathrm{p}=0.395 \text { (ns) }\end{array}$} \\
\hline & Asian & $3(20 \%)$ & - & - & \\
\hline & Black & $1 \quad(6.67 \%)$ & $1(11.10 \%)$ & - & \\
\hline \multirow{2}{*}{ Gender } & Female & $12(80 \%)$ & $9(100 \%)$ & $6(100 \%)$ & \multirow{2}{*}{$\begin{array}{c}\text { Chi-square } \\
\mathrm{p}=0.189 \text { (ns) }\end{array}$} \\
\hline & Male & $3(20 \%)$ & - & - & \\
\hline \multirow{3}{*}{$\begin{array}{l}\text { Duration of } \\
\text { complaint }\end{array}$} & Mean \pm SD & $62.80 \pm 58.74$ & $96.00 \pm 84.85$ & $79.33 \pm 61.94$ & \multirow{3}{*}{$\begin{array}{c}\text { ANOVA } \\
\mathrm{p}=0.532 \text { (ns) }\end{array}$} \\
\hline & Median value & 36 & 78 & 24 & \\
\hline & Range & $0-180$ & $36-300$ & $8-180$ & \\
\hline
\end{tabular}

SD: standard deviation. ns: no statistical significance. *For the variable duration of complaint, $\mathrm{n}=8$.

sis prevalence gradually increased in subgroups according to their higher degree of dysfunction (7.0\%, $11.1 \%$ and $50.0 \%$, respectively, for subgroups I, II and III). In subgroup I, there was also higher prevalence of rectification (57.1\%).

\section{DISCUSSION}

Cervical spine X-ray tracings did not indicate significant statistical differences between test and control groups, a finding that did not occur when evaluations were made by the physical therapists for the same X-rays (Table 3). Research studies point out tracing alterations in TMD patients' lateral head and cervical spine teleradiographs, sug- gesting that stomatognathic system conservative therapy for these patients may alter pre- and posttreatment X-ray tracings ${ }^{6}$.

Cranium-odontoid and odontoid-C3/C4 angle values (Table 3 ) do not indicate that head and cervical spine posture variations measured on the $\mathrm{X}$ rays are related to TMD, as reported by Huggare, Raustia $^{6}$ (1992). On the other hand, radiographic interpretations made by the physical therapists demonstrated more pronounced cervical spine curvatures for the test group. Probably, clinical diagnosis allows a more comprehensive evaluation of spine curvature, as compared to X-ray tracings. Hyperlordotic characteristics, coupled with an anterior forward head projection pattern in TMJ 
Munhoz WC, Marques AP, Siqueira JTT. Radiographic evaluation of cervical spine of subjects with temporomandibular joint internal disorder. Braz Oral Res 2004;18(4):283-9.

TABLE 5 - Number of masticatory muscles tender to touch in subgroup subjects.

\begin{tabular}{c|c|c|cc}
\hline \hline $\begin{array}{c}\text { Number of } \\
\text { tender muscles }\end{array}$ & $\begin{array}{c}\text { Subgroup I } \\
\mathrm{n} \mathrm{( \% )}\end{array}$ & $\begin{array}{c}\text { Subgroup II } \\
\mathrm{n} \mathrm{( \% )}\end{array}$ & \multicolumn{2}{|c}{$\begin{array}{c}\text { Subgroup III } \\
\mathrm{n}(\%)\end{array}$} \\
\hline 0 & $7(46.6 \%)$ & $0(0.0 \%)$ & 0 & $(0 \%)$ \\
\hline $1-3$ & $8(53.3 \%)$ & $5(55.5 \%)$ & 0 & $(0 \%)$ \\
\hline$>3$ & $0(0.0 \%)$ & $4(44.4 \%)$ & $6(100 \%)$ \\
\hline
\end{tabular}

TABLE 6 - Cervical spine X-ray diagrams in the three subgroups.

\begin{tabular}{|c|c|c|c|c|c|}
\hline \multicolumn{2}{|c|}{ Variables } & $\begin{array}{l}\text { Subgroup I } \\
(\mathrm{n}=14)^{*}\end{array}$ & $\begin{array}{l}\text { Subgroup II } \\
(\mathrm{n}=9)\end{array}$ & $\begin{array}{c}\text { Subgroup III } \\
(\mathrm{n}=6)\end{array}$ & ANOVA \\
\hline \multirow{3}{*}{$\begin{array}{l}\text { Cranium basis- } \\
\text { odontoid angle }\end{array}$} & Mean \pm SD & $87.83 \pm 7.41^{\circ}$ & $91.46 \pm 7.08^{\circ}$ & $89.59 \pm 9.79^{\circ}$ & \multirow{3}{*}{$\mathrm{p}=0.56(\mathrm{~ns})$} \\
\hline & Median value & $88.68^{\circ}$ & $92.90^{\circ}$ & $90.23^{\circ}$ & \\
\hline & Range & $76^{\circ}-99.64^{\circ}$ & $83.01^{\circ}-101.59^{\circ}$ & $75.79^{\circ}-101.92^{\circ}$ & \\
\hline \multirow{3}{*}{$\begin{array}{l}\text { Odontoid-C3/C4 } \\
\text { angle }\end{array}$} & Mean \pm SD & $11.08 \pm 5.30^{\circ}$ & $10.52 \pm 4.52^{\circ}$ & $10.05 \pm 4.96^{\circ}$ & \multirow{3}{*}{$\mathrm{p}=0.91(\mathrm{~ns})$} \\
\hline & Median value & $10.23^{\circ}$ & $9.27^{\circ}$ & $9.98^{\circ}$ & \\
\hline & Range & $1.65^{\circ}-19.25^{\circ}$ & $4.59^{\circ}-17.33^{\circ}$ & $2.30^{\circ}-16.04^{\circ}$ & \\
\hline \multirow{3}{*}{$\begin{array}{l}\text { X-ray } \\
\text { interpretation }\end{array}$} & Rectification & $8(57.1 \%)$ & $2(22.2 \%)$ & $2(33.3 \%)$ & \multirow{3}{*}{$\mathrm{p}=0.06(\mathrm{~ns})$} \\
\hline & Physiologic lordosis & $5(35.7 \%)$ & $6(66.7 \%)$ & $1(16.7 \%)$ & \\
\hline & Hyperlordosis & $1(7.0 \%)$ & $1(11.1 \%)$ & $3(50.0 \%)$ & \\
\hline
\end{tabular}

ns: no statistical significance. SD: standard deviation. ${ }^{*}$ One patient was excluded from this subgroup during the research.

internal disorder subjects is a typical finding, reviewed by Gonzalez, Manns ${ }^{4}$ (1996).

Cervical spine lateral X-ray interpretation also indicated certain differentiating subgroup III characteristics in relation to subgroups I and II, although not statistically significant (Table 6), such as a higher prevalence of hyperlordosis for subgroup III $(50 \%)$ contrasting with subgroups II $(11 \%)$ and I (7\%); and lower rectification $(33.3 \%$ for subgroup III and $53.3 \%$ for subgroup I).

A marked feature in subgroup III subjects was the increasing TMD severity associated to the number of masticatory muscles involved (Table 5) and not necessarily related to a compromising TMJ pathology. Therefore, it can be suggested that cervical spine X-ray profile alteration could be related to the worsening of masticatory muscle pathology and could be linked to reflexive neuromuscular factors.

Findings for the test and control groups lead to the conclusion that patients suffering from TMJ ID

\section{REFERENCES}

1. Darlow LA, Pesco J, Greenberg MS. The relationship of posture to myofascial pain dysfunction syndrome. J Am Dent Assoc 1987;114:73-5. show a tendency towards increased morphologic and functional alterations of the cervical spine (Table 3).

Results also revealed a subtle - but not statistically significant - tendency toward cervical spine hyperlordosis in subjects suffering from severe ID. At the same time, results also seem to suggest that in order to detect these cervical spine posture variations, direct observation and interpretation of $\mathrm{X}$-rays provide a better result than making tracings on them.

\section{CONCLUSION}

Results of this study revealed cervical spine hyperlordosis prevalence in TMJ internal disorder subjects, suggesting a relationship with TMD severity.

However, further studies involving only subjects suffering from severe TMD should be carried out in order to corroborate the present findings.

2. de Wijer A. Distúrbios temporomandibulares e da região cervical. São Paulo: Santos; 1998. 
Munhoz WC, Marques AP, Siqueira JTT. Radiographic evaluation of cervical spine of subjects with temporomandibular joint internal disorder. Braz Oral Res 2004;18(4):283-9.

3. Funakoshi M, Fujita N, Takehana S. Relations between occlusal interference and jaw muscle activities in response to changes in head position. J Dent Res 1976;55:68-72.

4. Gonzalez HE, Manns A. Forward head posture: its structural and functional influence on the stomatognathic system. A conceptual study. Cranio 1996;14:71-80.

5. Helkimo M. Studies on function and dysfunction of the masticatory system. II. Index for anamnestic and clinical dysfunction and occlusal state. Sven Tandlak Tidskr 1974;67:101-21.

6. Huggare JA, Raustia AM. Head posture and cervicovertebral and craniofacial morphology in patients with craniomandibular dysfunction. Cranio 1992;10:173-9.

7. Lee WY, Okeson JP, Lindroth J. The relationship between forward head posture and temporomandibular disorders. J Orofac Pain 1995;9:161-7.

8. Mannheimer JS, Rosenthal RM. Acute and chronic postural abnormalities as related to craniofacial pain and temporomandibular disorders. Dent Clin North Am 1991;35:185208.
9. $\mathrm{McNeill} \mathrm{CH}$ (ed.). The American Academy of Orofacial Pain. Temporomandibular disorders: guidelines for classification, assessment, and management. Chicago: Quintessence; 1993. p. 46-55.

10. Munhoz WC. Avaliação global da postura ortostática de indivíduos portadores de distúrbios internos da articulação temporomandibular: aplicabilidade de métodos clínicos, fotográficos e radiográficos [Dissertação de Mestrado]. São Paulo: Faculdade de Medicina da USP; 2001.

11. Nasri C, Teixeira MJ, Siqueira JTT. Ardência bucal: avaliação de uma amostra clínica. Rev Simbidor 2000;1:7582.

12. Viikari-Juntura E. Interexaminer reliability of observations in physical examinations of the neck. Phys Ther 1987;67:1526-32.

13. Woodhull AM, Maltrud K, Mello BL. Alignment of the human body in standing. Eur J Appl Physiol Occup Physiol 1985;54:109-15.
Received for publication on May 20, 2004

Sent for alterations on Sep 20, 2004 Accepted for publication on Dec 14, 2004

\section{ERRATA}

Na página 11 do volume 18, suplemento, um problema de incompatibilidade de fontes provocou erros nos logotipos de duas empresas patrocinadoras da $21^{a}$ Reunião Anual da SBPqO: Farmácia Fórmula \& Ação e DFL. As versões corretas dos logotipos são:

\section{Fórmula \& Ação}

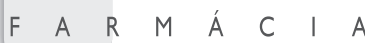

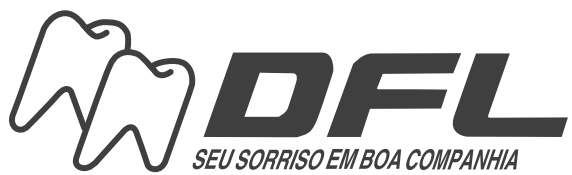

